\title{
Talking Back: Phillis Wheatley, Race, and Religion
}

\section{Keith Byerman}

Department of English, Indiana State University, Terre Haute, IN 47809, USA; keith.byerman@indstate.edu

Received: 9 March 2019; Accepted: 20 June 2019; Published: 25 June 2019

\begin{abstract}
This essay examines the means by which African American poet Phillis Wheatley uses her evangelical Christianity to engage issues of race in revolutionary America. In her poetry and other writings, she addresses and even instructs white men of privilege on the spiritual equality of people of African descent.
\end{abstract}

Keywords: Phillis Wheatley; race; religion; Thomas Jefferson

Several years ago, Henry Louis Gates, Jr., delivered the Jefferson Lecture for the National Council for the Humanities and subsequently published it as The Trials of Phillis Wheatley (Gates 2003). In it, he narrated the oft-repeated story of her meeting with a group of Boston gentlemen, who, at the behest of her master John Wheatley and her publisher, satisfied themselves that she had indeed written the poems for her book; their attestation was included in the front matter of the 1773 Poems of Various Subjects, Religious and Moral. Gates spends much of his lecture on the relationship between the poet and Thomas Jefferson, especially noting that the future president's highly negative comments on her were paradoxically echoed by Black Arts Movements critics of the 1960s and 1970s, though for very different reasons. Gates also observes that the view that Wheatley was largely imitative and too little concerned with racial experience continued to be dominant into the 1980s.

If he had extended his survey of scholarship into the new century, he would have seen a revision in the assessments of her. Much of the recent commentary has focused on the inherent ambivalence about race and black identity evident in the work; in addition, a number of critics have attended to her use of classical materials, the very thing that led to much of the earlier criticism. ${ }^{1}$ The point of this essay is to take seriously Wheatley's title, specifically the "various subjects, religious and moral." Whether scholars and artists denigrate or validate her, they tend to emphasize the neo-classical elements of her poetry; almost all, like Jefferson, see the religious aspect as secondary at best when discussing her writings (Jefferson 1984). ${ }^{2}$ What I contend is that it is through her verses and other writings on spiritual matters that we can see her engagement, implicitly and explicitly, with issues of race. Like the creators of the spirituals and many of the slave narratives, she uses her faith as an alternative source of sustenance, identity, and authority in a society that refused to acknowledge her fundamental humanity.

In Notes on the State of Virginia (1785), Jefferson specifically questions the relationship of religion to poetry. He says, "Among the blacks is misery enough, God knows, but no poetry. Love is the peculiar oestrum of the poet. Their love is ardent, but it kindles the senses only, not the imagination. Religion, indeed, has produced a Phyllis Whately; but it could not produce a poet. The compositions produced under her name are below the dignity of criticism. The heroes of the Dunciad are to her, as Hercules to the author of that poem" (267). For him, the religion of Wheatley lacks both rational and imaginative components and thus is consistent with his reading of her race as emotional and subhuman.

\footnotetext{
See Part 1 in Shields and Lamore.

2 As an exception that ultimately affirms my point, see Babacar M'Baye (2011), "The Pan-African and Puritan Dimensions of Phillis Wheatley's Poems and Letters," in Shields and Lamore (2011), pp. 271-78.
} 
The place to start considering Wheatley's counterargument, given this subject, is the frontispiece of her only book. Since Vincent Carretta makes clear that she had considerable involvement in the publication process, we can assume that she had control over this image (Carretta 2011). ${ }^{3}$ It is generally assumed to be the work of Scipio Moorhead, the slave of Reverend John Moorhead and trained by Sarah Moorhead, the minister's wife. The figure is framed by an oval band, clearly labeling Wheatley and indicating her race and station in life. Carretta has suggested in his biography that the band is a symbolic as well as literal boundary, suggesting the limits on her life (101). (Despite the designation, she was in fact a slave.) But the band can as easily be read as the illusion of an actual frame or medallion. What is also worth noting is that the subject is given her full name, even though it would be common, given her status, to have used only her Christian name. As a sidenote, George Washington, in response to her poem and letter to him, addresses her simply as "Phillis"; it is perhaps to this kind of verbal treatment that she is reacting in her claim of a surname, even if it is that of her owner. See Figure 1.

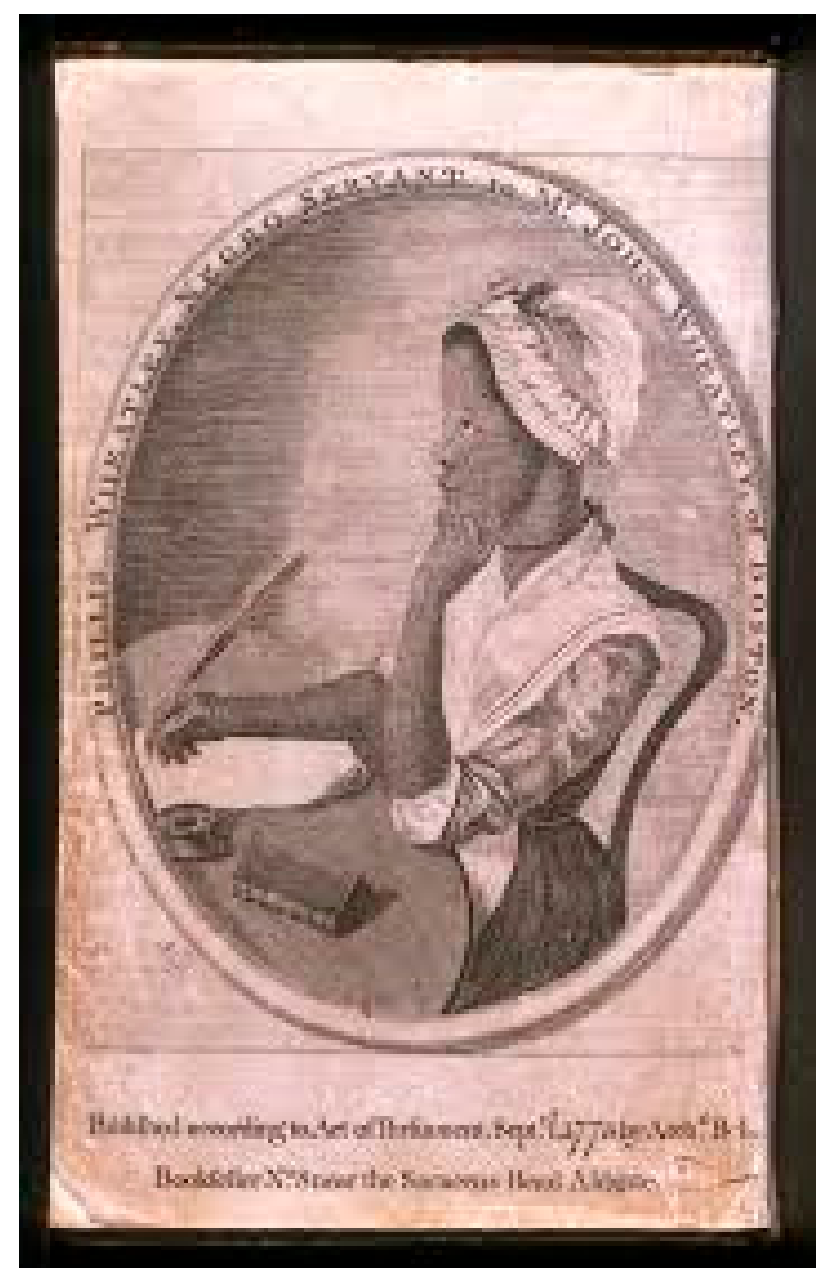

Figure 1. Frontispiece, Poems on Various Subjects, Religious and Moral.

Also noteworthy are the effects of lighting on her attire. While the clothes suggest the attire of a serving girl, light and shadow emphasize the folds and gloss of the dress and apron; this suggests richness in the fabric that is in clear contrast to the usual representations of servants. Attention is also drawn to her skin tone, which nearly matches the dress. The cap is rather fanciful, indicating that the

3 Phillis Wheatley: Biography of a Genius in Bondage (Athens: University of Georgia Press, 2011), pp. 94-101. Carretta also notes that Wheatley was the first colonial woman of any race to have a frontispiece attached to her writing and that the use of such an image of a living author was uncommon in the eighteenth century. 
wearer is not generally engaged in typical domestic work. Carretta comments that the throat choker is again a symbol of restriction and confinement; however, other domestic art of the period shows white women and black women wearing the same neck ornament (101).

Facially, she has slightly uplifted eyes, gazing into the middle distance, what we might call pouty lips, and fingers supporting the chin. It reflects a contemplative moment, perhaps awaiting inspiration from the muse. Consistent with this is the hand holding the quill above the page. She has already produced lines of text, so we are in fact at a moment of writerly pause in the midst of creative activity. It is also worth noting the book on the table. The binding was commonly known in the period as Revivalist Bible binding. ${ }^{4}$ Thus, it can be assumed that this is a Methodist Bible, but it is closed, suggesting that the subject is very familiar with the contents. Since she sat for this portrait, she has adopted the posture she wants to communicate to her readers. It defines her as a poet, and in doing so, contradicts the label of servant that defines her.

The presence of this particular version of the Bible links Wheatley to two key figures in the revivalist tradition: George Whitefield and the Countess of Huntingdon. Whitefield preached three times on his last American tour at Old South Church, where she was baptized, and once at the Wheatleys' home congregation, New South. While there is no specific record of Phillis's attendance at any of these events, it would be surprising if she did not, given her mistress Susanna's admiration of him. ${ }^{5}$ In the same year as the visit, Phillis wrote an elegy, "On the Death of the Rev. Mr. George Whitefield. 1770." In the poem, she addresses the "Great Countess," for whom Whitefield served as chaplain. The Countess was much sought after by and considerate of those of African descent, including Olaudah Equiano. In a number of cases, she served as a sponsor of their publications and agreed, in the case of Wheatley, to have the volume of poems dedicated to her.

These connections to Methodism encouraged in her a willingness to engage prominent people and even instruct them on religious matters. In one of the earliest poems in her collection, she presumes to lecture the students of Harvard. She emphasizes their privilege and their training in the methods of reasoning. At the same time, she asserts her difference from them:

Twas not long since I left my native shore

The land of errors, and Egyptian gloom:

Father of mercy, 'twas thy gracious hand

Brought me in safety from those dark shores.

("To the University")

Whatever one may think of the attitude toward Africa expressed here, the fact is that the poet wants to be very clear about her subject position. Unlike the students, she has had to move vast physical, cultural, linguistic, and spiritual distances to come to the religion that they were born into. Yet it is they, not she, who must be instructed about keeping the faith. Their scientific and philosophical training is a great opportunity, but it is nothing if they lose their moral foundations. It is useful to keep in mind that she was about fourteen when she wrote these lines, with only about seven years of schooling in English. Yet like a stern father, she instructs them:

Improve your privileges while they stay,

Ye pupils, and each hour redeem, that bears

Or good or bad report of you to heav'n.

Let sin, that baneful evil to the soul,

By you be shunn'd nor once remit your guard;

Suppress the deadly serpent in its egg.

4 See “The History Behind the 18th Century Revivalist Style. n.d ()," www.leonardsbooks.com.

Biography, 34 . 
Ye blooming plants of human race devine,

An Ethiop tells you 'tis your greatest foe.

Again at the end of the poem, she reminds them of her race, suggesting, among other things, that she will never have the chances in life that they will, but nonetheless claims equality in the only realm available to her, that of religious faith.

The piece that has provided the most negative attention is "On Being Brought from Africa to America," an eight-line poem dated 1768, which would make her approximately fifteen at the time of composition and with no more than seven years as an English speaker. The controversial part is found in the first four lines:

'Twas mercy brought me from my Pagan land,

Taught my benighted soul to understand

That there's a God, that there's a Saviour too:

Once I redemption neither sought nor knew.

$(13$; italics in original)

While "mercy" is not a term ever used elsewhere to refer to the Middle Passage of the slave trade, it is important to take into account the probable enthusiasm of her young conversion. After all, she was removed from her birth home before she was seven, and thus not of an age to have knowledge of her native belief system. It was "Pagan" in the eighteenth-century sense of not being Christian; her word choice would have been considered simply accurate and not pejorative at the time of its appearance. The fourth line on redemption, while it reflects some of the theological debates about whether those without knowledge of Christianity were damned, is almost absurd given the poet's age at the time of her kidnapping from her home. She is only recently past the age of spiritual accountability at the time of the poem's creation, to say nothing of her experience in Africa. The line simply puts her in the general category of those ignorant of belief, whether based on age or geography; in other words, it is another statement of fact, not a judgment on her race.

The final four lines return to her impulse in the previous poem to give instruction on race and religion to her "betters":

Some view our sable race with scornful eye,

"Their colour is a diabolic die."

Remember, Christians, Negros, black as Cain,

May be refin'd and join th' angelic train.

(13; italics in original)

Here again we see an act of ventriloquism as she speaks the voice of her antagonists. The quoted line sets up a word play with "diabolic" and "die," which then is doubled, since "sable" was a term to designate the color of mourning. In addition, it was so common in European lore for the devil to represented as black that the Puritans brought the notion to America. Thus, she locates in one line a complex of race, religion, history, and culture that captures the worldview of racism in her time.

One of the longest poems in her book is "Goliath of Gath," her retelling of the Biblical story of David's confrontation with the Philistine giant. Given its length and drama, it is surprising that it has not received any critical commentary, again suggesting that scholars have emphasized the classical and explicitly racial aspects of her work to the exclusion of the religious verse. She opens the work by using the discourse of neo-classical poetry to engage her Old Testament subject. She appeals to the muses to aid her in telling a tale of war. In the initial stanzas, she largely follows the narrative of First Samuel, in which the armies of Israel confront their frequent antagonists, the Philistines. From this enemy camp emerges Goliath in full battle regalia; he offers single combat to settle the conflict. He does this each day, and each day the Hebrew army withdraws in terror, until the shepherd boy David comes 
to bring supplies to his brothers. He offers to take up the challenge, to the amazement of the soldiers and the resentment of his older brother, who considers him a braggart. Wheatley makes two minor modifications to her Biblical source. The first is to change the consequences of losing. In the original, Goliath proposes that the defeated army will become the servants of the victors. But the poem states:

"For he who wins, in triumph may demand

Perpetual service from the vanquish'd land."

Thus, she turns the conflict into a struggle about slavery.

The second change reinforces the first. In both versions, the question is raised of the rewards for defeating Goliath. In First Samuel, they are purely economic: "and it shall be that the man who kills him the king will enrich with great riches, will give him his daughter, and give his father's house exemption from taxes in Israel" (I Samuel 17:25). In Wheatley's version, the first two are the same, but the third is distinct:

"Freedom in Israel for his house shall gain."

Moreover, this benefit is placed first in her list. With these subtle shifts, she has made this a struggle between slavery and freedom.

A more significant modification is the poet's introduction of a warning to Goliath against taking on the children of God. An angel comes to him and tells him specifically what is going to happen. To fight with Israel is to fight against omnipotent authority, even if it takes the form of an unprotected young man. But Goliath is, of course, defiant and must pay the consequences. In both versions, the actual confrontation is abbreviated, almost anticlimactic. Though David carries five stones, the first is slung so accurately that it fells the giant. The rest of the narrative is devoted to the routing of the Philistines, the beheading of Goliath by the hero, and, importantly, the identification of David's lineage. Here again the poet amends the original to note that he is from a small, but valiant, tribe.

In choosing this story, Wheatley aligns herself with the slave creators of spirituals, sermons, and trickster tales. These expressive forms linked the experiences of African Americans to those of the children of Israel and focused on the ways the young, weak, and small could triumph over their more powerful foes. These materials were ways to keep alive belief in justice and freedom in the face of oppression and humiliation. In addition, the methods used were consistently those of cleverness and intelligence rather than physical force. Like David, they rejected martial armor in favor of spiritual strength. David only needed the skill to find the weak spot in his enemy's defenses; when he did so, the battle was quickly over. This was the hope of the slaves as well, though they had to endure for a much longer time.

Finally, in reference to this poem, we can see a connection between the artist and her hero. Like him, she is young, small, and marginal. Like Eliab, who questioned the shepherd boy, many doubted Wheatley's right to come into the public arena and to speak. Like him, she felt that she had the right and the preparation to enter the field of battle, in her case, with the literary, social, and political giants. Like him, she used her faith as her form of armor. Her book became her smooth stone.

She used her power in other ways as well. In her writings are poems written to or about five of the seventeen men who conducted the "trial" that authenticated her text. All except one are part of the significant number (almost half) of her published poems that are on the theme of death. Most are in the form of elegies or addresses to members of the bereaved family. These tend to follow the pattern of an acknowledgement of the sorrow of the family, a statement of the virtues of the deceased, and conclude with an admonition to be happy that the soul of that person now rests in heaven, far from the troubles of this world. In the case of Thomas Hubbard, we have a poem addressed to his daughter, Thankfull Hubbard Leonard, when her husband died in 1771, and then one to the father when Thankfull dies the next year. The poem to Thankfull follows the general scheme, with part of the first stanza consisting of a comment to Death about his "incessant" destruction of human life, regardless of age, vocation, or affection. She then notes the devastation done to the mourner: "her last groan shall rend the azure sky." The second stanza then turns to a repudiation of sorrow: 
But cease thy tears, bid ev'ry sigh depart,

And cast the load of anguish from thine heart.

The reason to stop grieving is that the mourner must imagine her reunion with the beloved in heaven; she should prepare herself to join him where there are "pleasures more refin'd."

The poem to Thomas Hubbard provides an instructive variation on the pattern. It is useful to know that Hubbard was treasurer of Harvard College for twenty years and a prominent merchant; at one point, according to Gates, he had also been a slave dealer. Thus, he is an important member of the dominant white society that had enslaved Wheatley and countless others. He was also a model of status and authority for those Harvard students in the earlier poem.

The poem begins in the writer's conventional way, by noting the sorrow that Hubbard must be experiencing, but before the end of the first stanza, she has moved into the imperative mood:

Let Recollection take a tender part,

Assuage the raging tortures of your heart,

Still the wild tempest of tumultuous grief,

And pour the heav'nly nectar of relief:

Suspend the sigh, dear Sir, and check the groan.

In other words, she instructs this distinguished gentleman in how to behave even in matters of private emotion. The reason for this is that Thankfull has been a person of great virtue whose place in heaven is assured. Thus, she has gladly moved into the afterlife and escaped the troubles of this world. Consistently in these poems, Wheatley represents heaven as a space of freedom, of peace, and of release from the sorrows of life. In this she is much like the creators of the spirituals, whose expressions we have now come to see, not as mere resignation, but as a form of resistance to enslavement.

The new element in this poem is an act of ventriloquism; the poet speaks in the voice of the deceased. While the words that are spoken are part of the convention of resignation and acceptance, what is significant is the presumption of the slave to speak in the voice of the mistress. Given the views of Jefferson and many others about the moral and intellectual capacity of blacks, Wheatley's claim that she knows the mind and feelings of a cultivated white woman and has the right to speak them publicly is a challenge to white authority and superiority.

Finally, to bring the argument full circle, I want to look at a letter and a poem that implicitly bring us back to Jefferson. The poem engages in theological polemics. Among the poems in her 1772 Proposals, but not in the published work, are two pieces, both dated 1767, entitled "An Address to the Atheist" and "An Address to the Deist." Each calls on the addressee to turn away from unbelief, and each refuses to acknowledge in any way the validity of the other's views. The attack on Deism focuses specifically on any questioning of the trinity and threatens eternal damnation for any doubts on this issue. She also uses the standard argument that the unbeliever will come to his senses at the last moment, but that it will be too late to avoid divine retribution.

To this point, the poem appears to offer little beyond evangelical rhetoric of the sort found in the sermons of George Whitefield, whom Wheatley elegized in another work. But there are a few points to distinguish these verses. First, it opens with the line, "Must Ethiopians be employ'd for you?" We are offered no context for this, unlike the address to the Harvard students. But clearly it has the same implications. Though the deist may be a person of privilege, his religious error places him in a position to be admonished and taught by a believer, even one in the lowest position in society. He is so far astray that one he considers an inferior can lead him back to the path of righteousness. His status does not preclude him from needing the aid of one who he has labeled pagan and savage. The line, in other words, immediately subverts the conventional social hierarchy by claiming a higher order of things. The word "employ' $\mathrm{d}$ " skillfully retains the appearance of conventional power but undermines it by suggesting that it is the "Ethiopian" who has been sent to save the deist.

Furthermore, Wheatley asks the deist to "Attend to Reason whispering in thine ear." Deism, as we know, was in fact one of the theological expressions of the Enlightenment, of Reason itself. But for 
Wheatley, the apparently self-evident truths of Christianity were a form of rationality higher than that of her antagonist. Arguments against the trinity and against belief in general were irrational in the clear light of faith. And refusal to accept the tenets of that faith had predictable outcomes and thus required acceptance in the same way as mathematical problems.

Several years later, she has a brief correspondence with Samuel Occum (Occum 2006), the well-known Mohegan Indian who became an evangelical missionary to Natives Americans in the New York-New England area. Occum apparently knew the entire Wheatley family from his visits to Boston; there are letters to and from Susanna, Phillis's mistress. ${ }^{6}$ While his letter to the slave seems lost, her response indicates that he had expressed clearly anti-slavery views. Her text was reproduced in the Connecticut Gazette; and Universal Intelligencer as a "specimen of her ingenuity" (Complete Writings, 152) (Wheatley 2001). In it we see her most direct statement of her attitude toward slavery and enslavers.

The bulk of the letter is one long, periodic sentence that weaves together her Enlightenment, religious, and racial views:

I have this day received your obliging kind Epistle, and am greatly satisfied with your Reasons respecting the Negroes, and think highly reasonable what you offer in Vindication of their natural Rights; Those that invade them cannot be insensible that the divine Light is chasing away the thick Darkness which broods over the Land of Africa; and the Chaos which has reign'd so long, is converting into beautiful Order, and reveals more and more clearly, the glorious Dispensation of civil and religious Liberty, which are so inseparably united, that there is little or no Enjoyment of one without the other: Otherwise, perhaps, the Israelites had been less solicitous for the Freedom from Egyptian Slavery; I do not say that they would have been contented without it, by no means, for in every human Breast, God has implanted a Principle, which we call Love of Freedom; it is impatient of Oppression, and pants for Deliverance; and by the Leave of our Modern Egyptians I will assert, that the same Principle lives in us. God grant Deliverance in his own Way and Time. (pp. 152-53)

She employs Revolutionary rhetoric in claiming a universal natural right to freedom, and while her comments about African benightedness are consistent with her other work, she also suggests a historical evolution that links Christian conversion to a desire for "civil and religious Liberty" and further claims that these two are inseparable. She also reveals a developing sense of her homeland by asking leave of "Modern Egyptians" to assert that the same love of freedom and "impatience of Oppression" found in white Christians is also embedded in those of African descent. Her use of the pronoun "us" marks her as a new African, enlightened, Christian, and freedom-loving.

The last part of the letter is a frontal attack on those who proclaim liberty but hold slaves. While she says that she does not wish them harm, she does seek "to convince them of the strange Absurdity of their conduct whose Words and Actions are so diametrically opposite" (153). She turns the principles of reason and natural rights into weapons against the defenders of slavery, those very people who have been using them in support of revolution. These "enlightened" men cannot help but utter "strange Absurdities." Given the pretentions of many of the founding fathers, the sarcasm of her final sentence is evident: "How well the Cry for Liberty, and the reverse Disposition for the Exercise of oppressive Power over others agree,-I humbly think it does not require the Penetration of a Philosopher to determine" (153). Religion, race, and reason come together to suggest her understanding of her situation in the emerging new nation.

The argument, then, comes back to its beginning. Jefferson is one of the best-known deists of that era, author of some of the key documents of American freedom, and unrepentant if not untroubled slave holder. While his attack on Wheatley is published a few months after her death, she would seem to launch here pre-emptive attacks. His assault on her and on blacks generally assumed that they were

6 Curiously, in one of these letters, Occum refers to Phillis as "the Little Miss." Presumably, this is a term of endearment rather than condescension. Samson Occum to Susannah [sic] Wheatley, 21 September 1773. 
incapable of both reason and poetic imagination. What she does here and throughout her religious writings is to shift the terms of the discourse in such a way that she can gain some control over the representation of herself and her race. While she often adopts an apparently self-effacing mode of speaking, she always claims the right of the "Ethiop" to speak to power. She uses precisely those qualities, imagination and reason, she is said to lack. Like David, she takes on the giants on their own turf, and like him, at least in the spiritual sense, emerges the victor.

Conflicts of Interest: The author declares no conflict of interest.

\section{References}

Carretta, Vincent. 2011. Phillis Wheatley: Biography of a Genius in Bondage. Athens: University of Georgia Press.

Gates, Henry Louis. 2003. The Trials of Phillis Wheatley: America's First Black Poet and Her Encounters with the Founding Fathers. New York: Basic Civitas Books.

Jefferson, Thomas. 1984. Jefferson: Writings. Library Classics. New York: Library of America.

M'Baye, Babacar. 2011. The Pan-African and Puritan Dimensions of Phillis Wheatley's Poems and Letters. In New Essays on Phillis Wheatley. Edited by John C. Shields and Eric D. Lamore. Knoxville: University Tennessee Press, pp. 271-78.

Occum, Samuel. 2006. The Collected Writings of Samuel Occum, Mohegan. Edited by Joanna Brooks. New York: Oxford University Press.

Shields, John C., and Eric D. Lamore, eds. 2011. New Essays on Phillis Wheatley. Knoxville: University of Tennessee Press.

The History Behind the 18th Century Revivalist Style. n.d. Available online: https://www.leonardsbooks.com/whatwe-can-do/leonards-specialty-rebinding-styles/the-18th-century-revivalist_style/history-revivalist-style/ (accessed on 21 May 2019).

Wheatley, Phillis. 2001. Phillis Wheatley: Complete Writings. Edited by Vincent Carretta. New York: Penguin.

(C) 2019 by the author. Licensee MDPI, Basel, Switzerland. This article is an open access article distributed under the terms and conditions of the Creative Commons Attribution (CC BY) license (http://creativecommons.org/licenses/by/4.0/). 